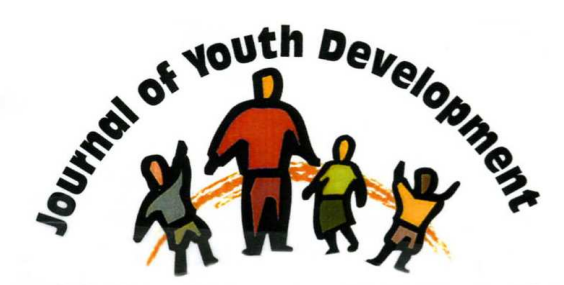

Bridging Research \& Practice

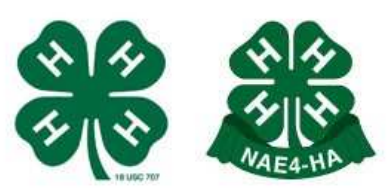

\title{
Promoting Youth Development Worldwide: The Duke of Edinburgh's International Award
}

\author{
Eva van Baren \\ Rotterdam School of Management \\ Rotterdam, The Netherlands \\ ebaren@rsm.nl \\ Marieke Meelen \\ Leiden University Centre for Linuistics \\ Leiden, The Netherlands \\ m.meelen@hum.leidenuniv.nl
}

Lucas C.P.M. Meijs

Rotterdam School of Management

Rotterdam, The Netherlands

Imeys@rsm.nl 


\title{
JOURNAL OF YOUTH DEVELOPMENT \\ bridging research and practice

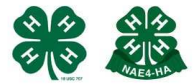

Volume 10, Number 1, Spring 2015

Article 151001PA002

\section{Promoting Youth Development Worldwide: The Duke of Edinburgh's International Award}

\author{
Eva van Baren and Lucas C.P.M. Meijs \\ Rotterdam School of Management \\ Marieke Meelen \\ Leiden University Centre for Linguistics
}

\begin{abstract}
The Duke of Edinburgh's International Award is a youth achievement Award program that aims to engage young people in purposeful activities focused on gaining knowledge, broadening horizons and accumulating a diversity of experiences. The program promotes positive youth development through an experienced based learning approach and is known to play a vital role in providing opportunities for young people to develop essential life skills, complementing their formal education. Comprised of three levels (Bronze, Silver and Gold) and four sections (Service, Skills, Physical Recreation and Adventurous Journey) the Award is designed to provide a balanced programme of personal development. The Award operates worldwide in over 140 countries and territories, through the International Award Association. This article will discuss The Duke of Edinburgh's International Award program and its non-formal educational framework. Participants reported that it has enabled them to grow in confidence and in their ability to contribute positively to their communities.
\end{abstract}

\section{Introduction}

The Duke of Edinburgh's (DofE) International Award, hereafter referred to as the Award, is a youth achievement Award program developed around bringing together practical experiences and life skills with the aim to equip young people for life (DofE, 2012a). The main guiding principle underlying the Award program is the individual challenge for the participants to develop personal skills, undertaking activities to reach new goals, work in a team and enhance community spirit. The Award is achievable by any young person between the age of 14 and 24, regardless of their background and circumstances. The latter is based on the notion that all 
young people should get the chance to develop life skills and enjoy the practical experiences they require in order to embrace any future challenges and opportunities.

The program consists of three levels: Bronze, Silver and Gold. At each level, participants set their own personal goals in each section: Service, Skills, Physical Recreation and an Adventurous Journey. There is also an additional requirement to complete a Residential Project for the Gold level. The four sections are designed to provide a balanced program of personal development (DofE, 2012b). They are primarily aimed at engaging young people in purposeful activities with a focus on gaining knowledge, broadening horizons and accumulating a diversity of experiences and perspectives. The structure of the program falls within the scope of experience-based learning as it enables participants to learn by doing (Kolb, 1976, 1984; Conrad, \& Hedin, 1991; Ferguson, 1992; Markus, Howard, \& King, 1993).

The landscape in which the Award operates today is changing. The International Award Foundation believes that the challenges young people now face have never been greater and that they need more support preparing for adult life. This seems to be especially true for those living in less developed regions of the world where issues such as poverty, HIV/AIDS and climate change affect youth to a greater extent. Where formal education systems often fail to fully prepare young people for the economic, political and social roles within their communities, the Award believes it can play a vital role in providing the tools young people need to develop essential life skills, complementing their formal education (DofE, 2012c).

Through its voluntary program and structure, multiple issues are addressed, including isolation, apathy, and alienation, among other by-products of modern day individualism. The pathway outlined by the program's theory of change results in the development of social and technical skills, physical recreation and the spirit of volunteerism. Our aim is to analyze the Award and contribute to a better understanding of experienced-based learning models that are implemented across the extraordinarily diverse universe of youth development programs.

\section{History \& Organisation}

\section{Background}

The Award was established in 1956. The original idea came from Kurt Hahn, a German philosopher and educationalist. Hahn was head teacher of Gordonstoun in Scotland from 1934 to 1953 (Cobb, 1986). At this school, HRH the Duke of Edinburgh completed his Moray Badge, a precursor of the Award (DofE, 2012b). After the Second World War, Hahn approached the Duke of Edinburgh to establish a national badge scheme based on the Moray Badge. It was during this time that there was a growing concern about the development of boys, due to the gap between leaving school at the age of 15 and entering National Service after they turned 18. The Duke of Edinburgh agreed to become chair and Hahn's vision of a nationwide Award was conceived (Maccariello, 2006). Hahn believed that practical involvement and a holistic approach was the key to learning which is why he advocated experiential education. Based on this philosophy, the Award was originally designed around four sections: Rescue \& Public Service Training, the Expedition, Pursuits \& Projects, and Fitness. Moreover, the program had to be available to all who wanted to participate, regardless of their race or socio-economic background (Hahn, 1936).

\section{The Award in the UK}

Although initially only aimed to reach boys between the age of 14 and 18 , a similar scheme for girls was launched in 1958 as the Award grew in prominence. By that time, 7000 boys had been 
participants and 1000 of those had achieved Awards (Cobb, 1986). The Award continued to evolve over subsequent decades, until 1980. At this point, the lower age limit was reduced to 14 , the upper age limit was extended to 25, and the Award took on its current four-section format of Service, Adventurous Journey, Skills and Physical Recreation. Currently, over 300.000 young people are taking part in the Award program in the U.K. every year (DofE, 2013a).

\section{The Award Goes Global}

Interest in the Award from outside the UK grew instantly after the Award was launched. Initially, it spread through the enthusiasm of international schools across the British Commonwealth leading to the formation of The Duke of Edinburgh's Award International Association in 1988. By 1989, the Award was operating in 48 countries as it spread beyond the boundaries of the Commonwealth, sometimes under slightly different names, such as 'The President's Award' in Kenya, 'The National Youth Achievement Award' in Singapore and 'The Duke of Edinburgh's Award Young American's Challenge' in the United States.

Over the last 50 years, the Award has developed and grown, reaching more and more young people around the world. As a result, over 140 countries and territories are currently delivering the Award, targeting all youth, including those who have not previously had opportunities for personal development. Recent Award projects around the world have focused on involving young offenders, those with disabilities, street kids and aboriginal communities. Since the principles of the Award have endured, The Duke of Edinburgh and his son HRH Prince Edward, who also has participated in the program, remain committed to the Award. Through adaptation and the continuous evolvement of its activities and delivery required to suit the changing demands and needs of youth around the world, the Award claims to be "recognized as the world's leading achievement Award for young people" (DofE, 2012b, p.11).

\section{Activities}

The Award activities are part of three progressive levels leading to a Bronze, Silver or Gold Award when successfully completed. At each level, participants are required to set their own personal goals in four different sections: (1) Service, (2) Skills, (3) Physical Recreation and (4) Adventurous Journey. Achievement is based on personal improvement and development within each of the three levels and is recorded using a record book acquired on enrollment. After completing each level of the Award, participants receive a certificate and a pin and/or medal during a recognition ceremony.

The minimum timescale for each section at Bronze level is three months. In addition, all participants must complete an extra three months in Physical Recreation, Skills or Service. The Adventurous Journey lasts two days and one night. Once participants have reached the Silver level, the duration of each section becomes six months. Non-Bronze Award holders must also do an extra six months in Physical Recreation, Skills or Service. At this level, the Adventurous Journey lasts three days and two nights. Finally, at the Gold level each section will take 12 months to complete and the Adventurous Journey will take four days and three nights. NonSilver Award holders must do an extra six months in either Physical Recreation, Skills or Service at this stage plus the additional requirement of a five-day Residential Project (DofE, 2012b). An overview can be found in the table below. 
Table 1

Minimum timescale for each level by section. Source: DofE handbook $6^{\text {th }}$ edition, $2012 b$, p.32

\begin{tabular}{|c|c|c|c|c|c|}
\hline & $\begin{array}{l}\text { Physical } \\
\text { Recreation }\end{array}$ & Skills & Service & Plus... & $\begin{array}{l}\text { Adventurous } \\
\text { Journey }\end{array}$ \\
\hline Bronze & 3 months & 3 months & 3 months & $\begin{array}{l}\text { All participants } \\
\text { must do an } \\
\text { extra } 3 \text { months } \\
\text { in either } \\
\text { Physical } \\
\text { Recreation or } \\
\text { Skills or Service }\end{array}$ & $\begin{array}{l}2 \text { days }+1 \\
\text { night }\end{array}$ \\
\hline Silver & 6 months & 6 months & 6 months & $\begin{array}{l}\text { Non Bronze } \\
\text { holders must } \\
\text { do an extra } 6 \\
\text { months in } \\
\text { either Physical } \\
\text { Recreation or } \\
\text { Skills or Service }\end{array}$ & $\begin{array}{l}3 \text { days }+2 \\
\text { nights }\end{array}$ \\
\hline Gold & 12 months & 12 months & 12 months & $\begin{array}{l}\text { Non Silver } \\
\text { holders must } \\
\text { do an extra } 6 \\
\text { months in } \\
\text { either Physical } \\
\text { Recreation or } \\
\text { Skills or Service }\end{array}$ & $\begin{array}{l}4 \text { days }+3 \\
\text { nights }\end{array}$ \\
\hline
\end{tabular}

\section{Purpose \& Results}

Based on the idea that every young person is different, the personal challenges to achieve an Award are therefore also different for each participant. As such, "each young person should be encouraged to examine themse/ves, their interests, abilities, and ambitions, then set their challenges in the four different sections of the Award" (DofE, 2012b, p.12). In other words, young people do not need to compete with others to achieve an Award: it is about personal challenge.

\section{The Fundamental Principles}

The latest Award handbook (DofE, 2012b, p.13) describes the program's principles and what is considered to be beneficial to participants. Personal and social developments, although not specifically defined by the Award, lie at the heart of the program. The fundamental principles refer to a personal challenge and highlight individual improvement through persistence and achievement based on one's initial capabilities ("non-competitive"), one's own choice to become involved ("voluntary") and one's personal selection of activities within the four sections ("flexible"). Moreover, the Award has a particularly strict policy of no discrimination when it comes to gender, race, religion, political affiliation or any other personal circumstances ("available to all"). Even though the personal aspect may seem more immediately apparent, the social aspect is highlighted mostly through the value of teamwork through the interaction with, and the commitment and responsibility to others, and to oneself (Maccariello, 2006). 


\section{Benefits to Young People}

The Award handbook lists twelve benefits to participants, including behaviors, attitudes and highly transferable skills (DofE, 2012b, p.21). First, "self-belief" and "self-confidence" are considered central to participants' personal development. The Award aims to have a positive impact on young people's self-image and personal ability. Helping participants know and accept their own strengths and weaknesses may lead to greater awareness of their own potential. Second, this process requires an "independent and self-motivating attitude," although a "sense of responsibility to others" is considered equally important. Consequently, this may lead to "a connection to their broader society" as they learn to value social development and a sense of inter-dependence. Third, young people can benefit from "new or improved interests, skills, and abilities." Participants can develop "life skills" including health, negotiation, research, communication, as well as problem solving and presentation skills, as listed by The Award. Throughout the participatory process participants can learn to manage their time and work out the best way to operate their Award program. In doing so, a further potential benefit may be "the ability to make a plan and then make their plan happen." Finally, The Award scheme stresses the importance of acquiring "team skills," which in turn may lead to "new friendships" and "a willingness to try new things."

\section{Content \& Implementation}

\section{Sections}

The four-section program of the Award is based on the philosophy of experiential education (Kolb, 1976, 1984) where concrete experiences form the foundation of learning (Ferguson, 1992). Hahn (2004) believed that practical involvement was the key to learning:

The aim of education is to impel people into value forming experiences (...) to ensure the survival of these qualities: an enterprising curiosity, an undefeatable spirit, tenacity in pursuit (...) and above all, compassion (...). It is culpable neglect not to impel young people into experiences (p.2).

In experiential education, experiences are less abstract than those in traditional learning situations. Experiences show social issues in relation to theoretical concepts and motivate learning by making use of concrete examples (Conrad, \& Hedin, 1991; Markus, et al., 1993). Experiential education is based on a four-step cycle of learning developed by Kolb (1976) where experiences connect to more effective action (active experimentation) through reflective observations and abstract conceptualizations. Learning is considered most effective when a participant goes through all stages of the learning cycle. That is, when experiences are followed by rigorous reflection activities (See Figure 1). Greenway (1993) believes that reflecting on an experience is directly linked to learning. Likewise, Joplin (1981) argues that "it is the reflection process which turns experience into experiential education" (p.16). The Award promotes its educational value by highlighting that the review and reflection of young participant's activities are especially important in order to ensure that "they benefit from the impact that the Award hopes to provide" (DofE, 2012b, p.42). However, the ability to reflect upon and review an experience is not directly described or listed as one of the potential participant benefits. 
Figure 1

The four-stage experiential learning cycle (Kolb, 1976)

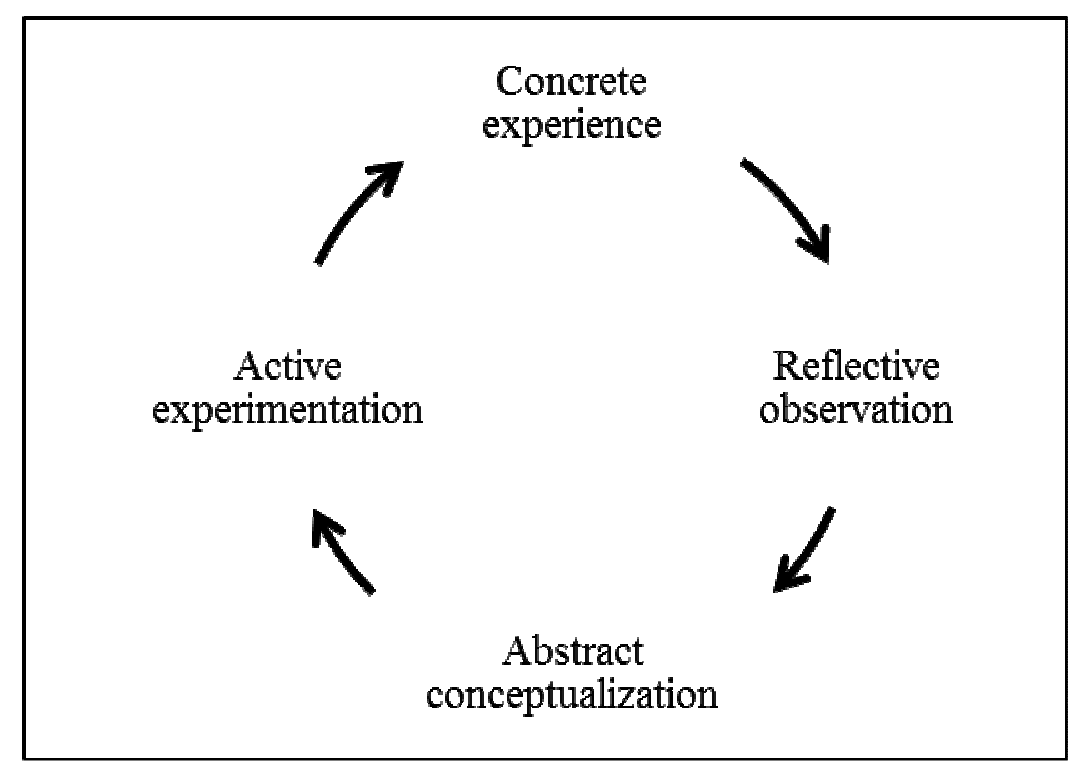

The handbook describes (DofE, 2012b) each of the four sections in detail (p.28). The Service section is aimed at understanding the value of giving service to others and the community. By undertaking service regularly over a period of time, rather than in a short concentrated time period, the Award program aims to contribute to the development of "a lifelong commitment to voluntary service and community involvement" (p.47).

The focus of the Skills section is on stimulating new interests or improving existing ones. As with all activities undertaken within the program, the list of possible activities depends on the individual interest of the participants and may therefore vary widely. Examples of skills can be found in sports, games, music, arts and crafts, nature and the environment, communication, technology and so on. According to the Award handbook, a level of commitment over time to progress in a skill leads to a "sense of achievement," "well-being" and possibly to "improved employability" (p.57).

Physical Recreation encourages participation in sport and other physical recreation with the aim to improve health, performance and fitness. The Award also believes that taking part in physical activity has many other benefits such as the improvement of team skills, self-esteem and participants' confidence as well as the enhancement of self-discipline, perseverance and selfmotivation. The handbook states that the requirements within this section apply equally to all young people, regardless of their physical ability (p.68). The key outcomes should be participation, persistence and improvement of general fitness.

The Adventurous Journey section seeks to provide participants with "a unique, challenging and memorable experience" (p.77). Here, the aim is to encourage a spirit of adventure and discovery while undertaking a journey in a (small) group. This particular section requires an unfamiliar and challenging environment, physically challenging activities and co-operation within a team. Prior to this journey participants must undergo relevant training which may include "practice journeys" to ensure that they have what it takes to be self-reliant and safe in the environment they choose. Furthermore, all journeys must have a clearly defined purpose and are supervised and assessed by experienced adults. There are three types of journeys: 
exploration, expedition or other adventurous journey. Whereas an exploration is as "a purpose with a journey," an expedition is defined as "a journey with a purpose" (p.83). In an exploration, more time and effort is spent on observing and collecting information relevant to the purpose and less on getting from one place to another. In other words, less time is spent on "journeying." In an expedition, the primary focus is on the journey itself and less on research and gathering information. Examples of explorations and expeditions are exploring the natural world, completing a challenging journey by foot, cycle or canoe and kayaking the entire navigable stretch of a river. Examples of other adventurous journeys, which involve "extra innovation," "creativity" and "challenge," include extensive sail across an ocean, climbing a high mountain or cycling from one end of a country to another.

For the completion of the Gold level, there is an additional requirement of doing a Residential Project. The aim is to broaden a participant's experience "through involvement with others in a residential setting" (p.88). The Award scheme states that during the Residential Project participants must share experience with those who are not their usual companions, by working towards a common goal. Ideally, the experience broadens the participant's outlook and horizons. Residential Projects can be activity based (e.g. sports coaching) or serve the purpose of helping others and communities (e.g. working with overseas aid charities) or the environment (volunteer work at a national park) and other young people (e.g. leadership training, youth camps). The idea is that, no matter the experience, it should have a lasting impact on the participant and those they have come in contact with, which is considered the "pinnacle" (p.92) of the journey through their Award.

\section{Requirements}

The Award is available to all young people between the age of 14 and 25 . The minimum starting ages for each level are: Bronze 14 years; Silver 15 years; Gold 16 years. Once participants have passed these minimum ages, they can enter the Award at any level. The minimum age for completing the Award at Bronze level is 14 years and 6 months. Bronze level Award holders should be at least 15 years and 6 months when completing their Silver Award whereas direct entrants at this level are required to complete their Award by the minimum age of 16. Once at Gold level, Silver level Award holders should complete their last Award by the minimum age of 17 while those who are direct entrants at Gold level should do so at 17 years and 6 months.

Time requirements are listed in Table 1 . The Award stresses the importance of individual challenge and therefore participants are encouraged to work at their own pace. While a mentor monitors progress, participants can take as long as they want to complete their Award, that is, within the required age limits. The handbook refers to the Award as a "marathon, not a sprint" (p.30). In other words, The Award cannot be achieved in a shorter time span by working more intensely as the objective is to develop a sense of commitment to a given task over time.

\section{Audience}

The Award is delivered internationally through the International Award Foundation. Within Award Units, Centers and Groups, the Award is delivered by educational institutions, employers, social clubs, youth organizations, young offenders institutions, religious organizations, sports clubs and civil organizations. However, in principle, the program is also open to young people who are not members of such formal organizations. 


\section{Impact}

Although The Duke of Edinburgh's Award has been operating for more than fifty years, little has been published or researched about the Award. Until thus far, authors have often referred to the Award in relation to, for example, its founder Kurt Hahn (James, 1980) or expeditions (Hattie, Marsh, Neill, \& Richards, 1997; Harper, 2004), and included it in more broad works. Today, there are very few independent program descriptions and impact evaluations that focus on specific versions of the Award. Those currently known to the authors are that of the German 'Das Jugendprogramm' (Kroll, 2007), the Canadian 'Le Prix Du Duc d'Édimbourg' (McKinsey, 2010), the 'Israel Youth Award' (Lipshitz, \& Gelber, 2008) and the U.K.'s Duke of Edinburgh's Award (Gibbs, \& Bunyan, 1997; Smith, \& Isles, 2003; 2004; Maccariello, 2006; Campbell, et al., 2009). Other than that, the Award has published various promotional and operational materials, including the handbook that extensively describes the scheme's principles and claimed benefits.

Several researchers have highlighted features of the holistic and experiential approach to learning, on which the Award program is based. For example, Rafferty (1997), Dobie and Macbeath (1998) and Maitles (1999) have argued that the experiential dimension of citizenship is a crucial aspect of citizenship education and consider it to be necessary in order to ensure genuine participation. Programs such as the Award provide opportunities for active engagement that young people perceive as purposeful and personally relevant. The Service section and the Adventurous Journey section of the Award seem to be ideally suited for developing citizenship skills. According to Smith and Isles (2004) the activities inherent to these sections may indeed provide opportunities for the development of personal skills and encourage active involvement within the community.

The value of outdoor activities, as represented in the Adventurous Journey section, in enhancing personal and social development is supported by a number of studies (e.g., Ewert, 1983; Ewert, 1989; Gibbs, \& Bunyan, 1997). A lot has also been written about the role of overseas expeditions in relation to these positive outcomes for young people (e.g., Grey, 1984; Kennedy, 1994; Allison, 1998; Beames, 2003, 2004, 2005). Findings from a small-scale study by Hopkins (1982) show that for many young people, the completion of this section was perceived as one of the greatest challenges of their lives, resulting in positive changes in their self-esteem (In Smith, \& Isles, 2004, p.35). Smith and Isles (2004) found that the involvement in outdoor education activities provide young people with the opportunity to develop basic leadership skills. These include the development of self-confidence and being able to take initiative. Participants regarded the latter as one of the long-term benefits of joining the program. Hahn (1957) believed that someone's self-confidence grew as they progressed in physical capability. He also thought that values achieved through outdoor education, or expeditions as he called it, make up the basis of education and "can greatly contribute towards building strength of character" (Hahn, 2004, p.1). Effects of adventure programs on self-esteem seem to exceed those of other educational programs (Hattie, et al., 1997). Fleming (2003) and Sleight (2005) found that Award participants involved in outdoor activities deeply appreciate what they learned and experienced. Key themes that have emerged from their reflections include challenge, teamwork, determination, excitement and a sense of achievement upon completion (in Macariello, 2006, p.34).

A study by Smith and Isles (2004) on the role of the Duke of Edinburgh's Award in the promotion and development of citizenship suggests that participation in the Award is "an appropriate mechanism for developing the personal skills and qualities associated with citizenship education" (p.27). By participating in the Award, young people become involved in service within the community. According to participants, it was one of the most challenging 
aspects of the program, as it required them to demonstrate a consistent commitment to others over a longer period of time. However, evidence from their study suggests that once they had become actively involved, "it became a particularly rewarding experience" (p.31). Since the introduction of the Award program in the prison system in 2010, more recent studies have focused on the potential impact of the Award on young offenders (e.g., Dubberley, 2010). Though preliminary in nature, results suggest that the Service section in particular may help those in custody to reconnect with the communities from which they have become alienated.

The information highlighted throughout this article is based on a limited number of publications and research currently available on the Award. The Award has recently committed to an evidence-based approach to evaluate their scheme, stating that "it is not enough for us to believe that what we do makes a difference - we must prove that it does, and become accountable to everyone we serve" (DofE, 2012c, p. 4). Increased knowledge and credibility of the program's worth could be supported by more in-depth study on its potential benefits and impacts carried out by those who are not directly connected to the Award organization.

\section{Conclusion}

The Award is a unique program using a well-structured intervention resulting in a comprehensive non-formal experience-based learning scheme. The four different sections and three levels make it both extensive and well-balanced, covering all areas of personal development for young people: increase their skills \& talents, improve their fitness, work in a team and contribute to society in the form of voluntary service. The national Award authorities delivering the program are part of a large global network. The program has the potential to extend its reach in even more than the 140 countries and territories already taking part because it is flexible enough to meet the objectives of local and national youth policies. Although the significant and measurable impact on the lives of young people seems to be apparent, future research will have to show which of the sections contribute the most and, furthermore, if the Award program as it is, proves to have a larger impact than other youth development programs.

Other suggestions for future research include the relation between the different sections and how they interact. Questions concerning the possible increased effect over time (participants going through all three levels) need to be researched, just like the differences in impact in various countries or target groups from different backgrounds.

The following website provides more detailed information about The Award and how to get involved, either as a participant, leader or volunteer: http://www.intaward.org/

\section{References}

Allison, P. (1998). Greenland: more questions than answers. Journal of Adventure Education and Outdoor Leadership, 2, 16-20.

Beames, S. (2003). Wrestling with development: Searching for the balance between give and take. Pathways: The Ontario Journal of Outdoor Education, 14(11), 33.

Beames, S. (2004). Overseas youth expeditions with Raleigh International: A rite of passage? Australian Journal of Outdoor Education, 8(1), 29-36. 
Beames, S. (2005). Expeditions and the social construction of the self. Australian Journal of Outdoor Education, $9(1), 14-22$.

Campbell, J., Bell, V., Armstrong, S.C., Horton, J., Mansukhani, N., Matthews, M., \& Pilkington, A. (2009). The impact of the Duke of Edinburgh's Award on young people. (Unpublished). Retrieved 13 February 2014, from: http://nectar.northampton.ac.uk/2447/

Cobb, D. (Ed.) (1986). 30 Years on: The story of The Duke of Edinburgh's Award 1956 - 1986. Windsor: The Duke of Edinburgh's Award.

Conrad, D., \& Hedin, D. (1991). School-based community service: What we know from research and theory. The Phi Delta Kappan, 72(10), 743-749

Dobie, T., \& MacBeath, J., (1998). Pupil Councils: A Case Study of Pupils Councils in Fife. University of Strathclyde Quality in Education Centre/Fife Council, Glasgow, Scotland.

Dubberley, S. (2010). Young Offenders, Imprisonment and The Duke of Edinburgh's Award. Ph.D. Thesis, University of Wales.

Ewert, A. (1983). Outdoor adventure and self-concept: A research analysis. Eugene: University of Oregon, Center of Leisure Studies.

Ewert, A. (1989). Outdoor adventure pursuits: Foundations, models, and theories. Columbus, $\mathrm{OH}$ : Publishing Horizons.

Ferguson, N.B.L. (1992). Becoming an active-learning centered teacher. Experiential Education, Nov-Dec, 6-9.

Fleming, J. (2003). Fort William to inverness. Canoe Focus, 141, 40-41.

Gibbs, C., \& Bunyan, P. (1997). The development of self-esteem through a Duke of Edinburgh's Award scheme. The Journal of Adventure Education and Outdoor Leadership, 14(2), 3-4.

Greenaway, R. (1993). Playback: A guide to reviewing activities. Windsor: The Duke of Edinburgh's Award in Association With Endeavour Scotland.

Grey, T. (1984). The expedition experience. Adventure Education, March/April, 17-18.

Hahn, K. (1936). Education and peace: The foundations of modern society. The Inverness Courier, pp. 1-4.

Hahn, K. (2004). Kurt Hahn Quotes. Retrieved 13 February 2014, from http://www.kurthahn.org/quotes/quotes.html

Hahn, K. (1957). Outward bound. New York: World Books.

Harper, M. (2004). Something else! Horizons, 27, 14-15. 
Hattie, J.A., Marsh, H.W., Neil, J.T., \& Richards, G.E. (1997). Adventure education and outward bound: Out-of-class experiences that make a lasting difference. Review of Educational Research, 6オ1), 43-87.

Hopkins, D., (1982). Changes in self-concept as the result of adventure training. Canadian association for Health and Recreation Journal, 48(6). Quoted in: Gibbs, C., \& Bunyan, P. (1997). The development of self-esteem through a Duke of Edinburgh's Award scheme. The Journal of Adventure Education and Outdoor Leadership, 14(2), 3-4.

James, T. (1980). Sketch of a moving spirit: Kurt Hahn. In: Warren, K., Sakofs, M., \& Hunt, J. (Eds.), The theory of experiential education. Dubuque, Iowa: Kendall/Hunt Publishing Company.

Joplin, L. (1981). On defining experiential education. In: Warren, K., Sakofs, M., \& Hunt, J. (Eds.), The theory of experiential education. Dubuque, Iowa: Kendall/Hunt Publishing Company.

Kennedy, A. (1994). Liverpool schoolboys Sahara expedition. Adventure Education, March/April, 19-20.

Kolb, D.A. (1976). Management and the Learning Process. California Management Review. $18(3), 21-31$.

Kolb, D.A. (1984). Experiential learning: Experience as the source of learning and development. New Jersey: Prentice-Hall.

Kroll, T. (2007). Und Alle Gehen Studieren!? - Das Internationale Jugendprogramm Und Seine Auswirkungen Auf Die Teilnehmerinnen: Sozialpädagogische Perspektiven aus Sicht der TeilnehmerInnen, Diplomarbeit. Munich: GRIN Verlag.

Lipshitz, C., \& Gelber, N. (2008). Evaluation of the "Israel Youth Award" to encourage teenagers to develop individual and social leadership through positive use of leisure time. The Branco Weiss Institute for the Development of Thinking. Jerusalem.

Maccariello, B. (2006). An exploration of The Duke of Edinburgh's Award in Thurrock, Essex. Dissertation. Morray House School of Education, University of Edinburgh.

Maitles, H., (1999). Political education in schools. International Journal of Inclusive Education, 3(2), 181-190.

Markus, G.B., Howard, J.P.F., \& King, D.C. (1993). Integrating community service and classroom instruction enhances learning: Results from an experiment. Educational Evaluationand Policy Analysis. 14(4), 410-419.

McKinsey, \& Company. (2010). Recognizing value to our communities. THE DUKE OF EDINBURGH'S AWARD LE PRIX DU DUC D'ÉDIMBOURG. Retrieved March $3^{\text {rd }} 2014$ from: http://www.dukeofed.org/background-on-mckinsey-study .

Rafferty, S. (1997). Giving children a voice? What next? A study from one primary school. Spotlights, 65, University of Glasgow, Scottish Council for Research and Education, Edinburgh.

Sleight, L. (2005). Wild Wabakimi. Canoe Focus, 157, 40-41. 
Smith, D., \& Isles, W. (2004). The Role of The Duke of Edinburgh's Award in the Promotion and Development of Citizenship. Teacher Researcher Programme 2003/2004.

The Duke of Edinburgh's International Award Foundation. (2012a). Transforming the Award: modernising to meet increasing demand and need. The Duke of Edinburgh's International Award Foundation, London.

The Duke of Edinburgh's International Award Foundation. (2012b). Award handbook $6^{\text {th }}$ edition. London.

The Duke of Edinburgh's International Award Foundation. (2012c). Measuring the Award's impact. London.

The Duke of Edinburgh's International Award Foundation. (2013a). Retrieved March 132014 from: http://www.dofe.org/en/content/cms/about-us/our-work/stats-facts/.

(c) Copyright of Journal of Youth Development Bridging Research and Practice. Content may not be copied or emailed to multiple sites or posted to a listserv without copyright holder's express written permission. Contact Editor at: patricia.dawson@oregonstate.edu for details. However, users may print, download or email articles for individual use.

ISSN 2325-4009 (Print); ISSN 2325-4017 (Online) 